\title{
Antibacterial activities of triterpenoidal compounds isolated from Calothamnus quadrifidus leaves
}

\author{
H. A. Ibrahim*, M. R. Elgindi, R. R. Ibrahim and D. G. El-Hosari
}

\begin{abstract}
Background: Calothamnus quadrifidus R.Br has many traditional uses and there are few reports about its chemical and biological activities. So our aim is to isolate the triterpenoidal compounds from dichloromethane fraction (DCMF) of Calothamnus quadrifidus R.Br leaves and in addition to evaluate the antibacterial activity of the isolated compounds.

Methods: DCMF of C. quadrifidus leaves was subjected to different chromatographic techniques to isolate pure triterpenoidal compounds which were identified using different chemical and spectroscopic techniques.

Antibacterial activities of the isolated compounds were evaluated using agar well diffusion method while minimum inhibitory concentration was assessed by microtiter plate assay method.

Results: Five compounds were isolated and they were betulinic acid (1), ursolic acid (2), 3-acetyl-23-hydroxy betulinic acid (3), 2,23-dihydroxy betulinic acid (4) and 2,21,23-trihydroxy betulinic acid (5) were isolated from DCMF of $C$. quadrifidus leaves for the first time. Compounds 4 and 5 showed strong antibacterial activity against $S$. typhimurium while compound 4, 5 and 3, 4 exhibits moderate effect against E.coli and S. aureus respectively.

Conclusion: Pure triterpenoidal compounds isolated from C. quadrifidus leaves showed antibacterial activities in different strengths.
\end{abstract}

Keywords: Antibacterial, Calothamnus quadrifidus, Myrtaceae, Triterpene

\section{Background}

Genus Calothamnus (F. Myrtaceae) is commonly known as the one-sided bottle brush or a claw flower and comprises about 40 species. It is native to south Western Australia [1] and it is also cultivated in Egypt. C. quadrifidus R.Br is an erect or spreading shrub of about three meter high with red flowers arranged in clusters on one side of the stem [2]. Few reports concerning the phytoconstitutents of $C$. quadrifidus, mainly focused on phenolics, including flavonols, flavanones, flavones, tannins and phenolic acids [3, 4] as well as evaluation of its essential oil was reported [3]. Moreover it was found that the aqueous ethanol extract of the aerial parts and aqueous methanol extract of leaves and stems for C. quadrifidus possesses analgesic, anti-inflammatory, hypoglycaemic and antioxidant

\footnotetext{
* Correspondence: haithamali081@gmail.com

Department of Pharmacognosy, Faculty of Pharmacy, Helwan University, EinHelwan, Cairo 11795, Egypt
}

activities [3, 4]. In addition, the essential oil of the aerial parts showed antimicrobial activity [3]. There were no reports about investigation of the triterpenoidal content, so we deemed it of interest to isolate and identify the triterpene compounds from DCMF of C. quadrifidus leaves and to evaluate the antibacterial activity of the pure isolates.

\section{Methods}

Instruments and material

Silica gel-60 (Fluka Chemie AG, Switzerland) and sephadex LH-20 (Sigma-Aldrich Steinheim, Germany) were used as an adsorbent for column chromatography as well as pre-coated silica gel plates $\mathrm{F}_{254}$ (Merck, Germany) were used for thin layer chromatography. $P$-anisaldehyde spray reagent was used for the detection of triterpenes. DCM/ MeOH; 95:5 $\left(\mathrm{S}_{1}\right)$; 90:10 $\left(\mathrm{S}_{2}\right) \mathrm{v} / \mathrm{v}$, were used as solvent systems. The NMR data was measured using Bruker Avance (600 and $150 \mathrm{MHz}$ for ${ }^{1} \mathrm{H}$ and ${ }^{13} \mathrm{C}$ NMR). Results were 
reported as $\delta$ ppm values relative to TMS as internal reference. The IR was carried out on FT/IR 300 E Jasco using $\mathrm{KBr}$ discs.

\section{Plant material}

C. quadrifidus R.Br leaves were obtained from research park at Saft El-laban area, Giza, Egypt, during the flowering stage (September 2016). It was identified by Dr. Trease Labib, former specialist of plant Taxonomy, El Orman Botanical Garden, Giza, Egypt. Voucher specimen (No.000105CC @ 05-01-05-01) was deposited at the herbarium of El Orman Botanical Garden, Giza, Egypt.

\section{Extraction and isolation}

Air dried C. quadrifidus leaves $(2 \mathrm{~kg})$ were extracted by reflux with $80 \%$ aqueous $\mathrm{MeOH}(5 \mathrm{~L})$ at law temperature $\left(40^{\circ} \mathrm{C}\right)$ for $4 \mathrm{~h}$. The filtrated aqueous $\mathrm{MeOH}$ was evaporated under reduced pressure and law temperature to afford $105 \mathrm{~g}$ of dry crude extract. The dry residue was suspended in $300 \mathrm{~mL} \mathrm{H}_{2} \mathrm{O}$ and successively fractionated with dichloromethane and ethyl acetate by liquid extraction $(3 \times 300 \mathrm{~mL})$. After evaporation of each solvent, a total of 35, 20 and $45 \mathrm{~g}$ of dichloromethane (DCMF), ethyl acetate and aqueous extract dry residue were obtained respectively. By application of the three fractions on TLC and spraying with $p$-anisaldehyde / sulphuric acid reagent which is characteristic for terpenoidal compounds [5], it was found that the DCMF is rich in terpenoidal compounds than other two fractions. Therefore the DCMF was used for further isolation of terpenoidal compounds. It was applied on normal phase silica gel column $(800 \mathrm{~g} \times 1000 \times 7 \mathrm{~cm})$ and eluted with gradients of n-hexane-ethyl acetate (8:2: up to 2:8). Thirty -five fractions of $250 \mathrm{~mL}$ each were collected and combined into five major fractions on the basis of their TLC. F-1 was found to be rich in fatty substance and contains traces of terpenoidal compounds. F-2 (1.3 g) was chromatographed on successive silica gel column using n-hexane-ethyl acetate mixture (4:6) as eluent to afford pure sample of compound 1 (19 mg). F-3 (2.5 g) was fractionated on silica gel column and eluted with $n$ - hexane- ethyl acetate mixture (3: 7) giving two main subfractions, each one contains crude sample of compound 2 and 3. For final purification of each one, they subjected on sephadex LH-20 column and eluted with $\mathrm{MeOH}$ to afford chromatographically pure samples of compounds $2(20 \mathrm{mg})$ and $3(25 \mathrm{mg})$. F-4 (3.4 g) was fractionated on silica gel column using DCM-MeOH (100:0 to $90-10)$ as eluent to give a fraction containing mixture of two compound which further purified using prep-TLC and DCM-MeOH (95:5) for development to yield pure samples of compound $4(11 \mathrm{mg})$ and $5(8 \mathrm{mg})$. It was found that F-5 $(0.5 \mathrm{~g})$ contains a complex mixture of minor compounds, so it is difficult to isolate them. Purity of the isolated compounds was established on the bases of their appearance under UV-254 and behaviour towards $p$-anisaldehyde/sulphuric acid spray reagent on TLC.

\section{Antibacterial activity \\ Materials}

Gram positive bacteria;Staphylococcus aureus (RCMB010010) and Bacillus subtilis (RCMB 015 (1) NRRL B_543) and Gram negative bacteria;Salmonella typhimurium (RCMB 006 (1) ATCC 14028) and Escherichia coli (RCMB 010052 ATCC 25955) were supplied from the Regional Center for Mycology and Biotechnology (RCMB), Al-Azhar University, Cairo, Egypt. Müller-Hinton Agar (Sigma-Aldrich Company, USA); ampicillin (October pharma, Egypt); gentamycin (Garamycin, MUP for Schering-Plough, Egypt); and Triphenyltetrazolium chloride (Sigma-Aldrich, Chemical Company USA) were used for antimicrobial evaluation.

\section{Susceptibility test}

The antibacterial activity of the isolated compounds was investigated using agar well diffusion method [6]. Gram negative and positive bacteria (two of each) were used. Muller Hinton agar was used for the bacterial growth $\left(45 \pm 2{ }^{\circ} \mathrm{C}\right)$. The inoculum was culture of each bacterial species in the $20 \mathrm{~mL}$ Muller Hinton agar diluted in the same medium to a final concentration of approximately $1 \times 108 \mathrm{CFU} / \mathrm{mL}(0.5 \mathrm{NTU}-\mathrm{McF}$ - 1 land scale). After that it poured into sterile Petri dish and left until complete solidification and Wells were made using $8 \mathrm{~mm}$ diameter of sterile cork borer. The initial solution of the tested compounds were prepared by dissolving $10 \mathrm{mg}$ in 1 $\mathrm{mL}$ dimethyl sulfoxide to obtain concentration of $10 \mathrm{mg} /$ $\mathrm{mL}$ and then $100 \mu \mathrm{g} / \mathrm{mL}$ was added to each well. Ampicillin and gentamycin $(5 \mathrm{mg} / \mathrm{mL})$ as anti-bacterial controls and dimethyl sulfoxide control were added into the wells, separately. Plates were incubated at $37^{\circ} \mathrm{C}$ for $24 \mathrm{~h}$. The antibacterial activity of the compounds was determined by measuring the diameter of clear zone around the well [6]. Three replicates were maintained for each experiment.

\section{Determination of minimum inhibitory concentration (MIC)}

$\mathrm{MIC}$ of the pure compounds (1-5) was measured using microtiter plate dilution method [7]. 2-fold serial dilutions of the compounds were carried out in $100 \mu \mathrm{L} \mathrm{nu-}$ trient broth to reach concentrations from 1000 to $4.7 \mu \mathrm{g} / \mathrm{mL}$ then the plates were incubated overnight at $37^{\circ} \mathrm{C}$. MIC was determined as the lowest concentration of compounds with no visible growth [8].

\section{Statistical analysis}

Data was analysed using one-way Analysis of Variance (ANOVA) followed by Tukey-Kramer Multiple Comparisons Test. The experimental results were expressed as a 
mean, \pm Standard deviation (SD). The difference between groups were considered significant when $p<0.001$. All analyses were performed using (GraphPad InStat ${ }^{\circ}$, version 3, USA) software.

\section{Results}

\section{Identification of the isolated compounds}

On the basis of their chromatographic properties including their appearance as violet color with $p$-anisaldehyde spray reagent, as well as spectral data (Table 1), it was found that the main skeleton of the compounds 1 and 3-5 (Fig. 1) belongs to lupane type [9].

Compound 1 was obtained as white crystals $(19 \mathrm{mg})$,

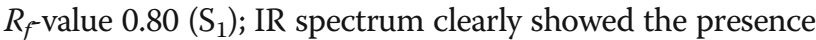
of carboxylic and hydroxyl groups at $3500-2500 \mathrm{~cm}^{-1}$ and broad band at $\approx 3400 \mathrm{~cm}^{-1}$ respectively, characteristic for lupane nucleus $[9,10]$. The ${ }^{1} \mathrm{H}-\mathrm{NMR}$ spectrum of 1 (Table 1) suggested that its structure may be betulinic acid based on the presence of six sharp singlets appearing at $\delta 1.65,1.32,1.11,0.93,0.87$ and 0.77 ascribed to the protons of six tertiary methyl groups $(\mathrm{H}-30, \mathrm{H}-23, \mathrm{H}-24$,

Table 1 The ${ }^{1} \mathrm{H}-\mathrm{NMR}(600 \mathrm{MHz})$ and ${ }^{13} \mathrm{C}-\mathrm{NMR}(150 \mathrm{MHz})$ data of compound 1 and $3-5$ (in DMSO); $\delta$ in ppm; $J$ in $\mathrm{Hz}$

\begin{tabular}{|c|c|c|c|c|c|c|c|c|}
\hline \multirow[t]{2}{*}{ Position } & \multicolumn{2}{|l|}{1} & \multicolumn{2}{|l|}{3} & \multicolumn{2}{|l|}{4} & \multicolumn{2}{|l|}{5} \\
\hline & $\overline{\delta C}$ & $\delta \mathrm{H}$ & $\overline{\delta C}$ & $\delta \mathrm{H}$ & $\delta C$ & $\delta \mathrm{H}$ & $\overline{\delta C}$ & $\delta \mathrm{H}$ \\
\hline 1 & 38.84 & & 38.20 & & 39.38 & & 40.75 & \\
\hline 2 & 27.61 & & 27.55 & & 67.43 & & 67.66 & \\
\hline 3 & 77.14 & 3.39 (1 H, brs) & 82.52 & $3.83(1 \mathrm{H}, \mathrm{s})$ & 77.30 & $3.62(1 \mathrm{H}, \mathrm{brs})$ & 82.65 & $3.62(1 \mathrm{H}, \mathrm{brs})$ \\
\hline 4 & 38.93 & & 38.87 & & 38.87 & & 40.40 & \\
\hline 5 & 55.25 & & 55.17 & & 55.87 & & 55.87 & \\
\hline 6 & 18.42 & & 18.43 & & 18.46 & & 77.35 & $2.13(1 \mathrm{H}, \mathrm{m})$ \\
\hline 7 & 34.37 & & 34.45 & & 36.82 & & 40.40 & \\
\hline 8 & 40.66 & & 40.49 & & 40.40 & & 39.38 & \\
\hline 9 & 50.36 & & 50.32 & & 48.97 & & 48.97 & \\
\hline 10 & 37.18 & & 37.22 & & 38.02 & & 38.02 & \\
\hline 11 & 20.91 & & 20.91 & & 21.54 & & 22.61 & \\
\hline 12 & 25.52 & & 25.47 & & 25.56 & & 23.81 & \\
\hline 13 & 38.04 & & 38.04 & & 38.95 & & 38.95 & \\
\hline 14 & 42.45 & & 42.45 & & 42.48 & & 42.48 & \\
\hline 15 & 30.55 & & 30.55 & & 31.81 & & 30.85 & \\
\hline 16 & 32.16 & & 32.16 & & 32.17 & & 32.17 & \\
\hline 17 & 55.94 & & 55.84 & & 55.87 & & 55.87 & \\
\hline 18 & 47.07 & & 47.02 & & 47.07 & & 47.07 & \\
\hline 19 & 49.07 & & 48.97 & & 48.93 & & 48.97 & \\
\hline 20 & 150.82 & & 150.67 & & 150.37 & & 150.60 & \\
\hline 21 & 29.66 & & 29.53 & & 29.09 & & 29.28 & \\
\hline 22 & 36.80 & & 36.70 & & 36.81 & & 36.81 & \\
\hline 23 & 28.55 & $1.32(3 \mathrm{H}, \mathrm{s}, \mathrm{Me})$ & 63.21 & $3.70(2 \mathrm{H}, \mathrm{s})$ & 62.87 & $3.69(2 \mathrm{H}, \mathrm{s})$ & 63.26 & $3.70(2 \mathrm{H}, \mathrm{s})$ \\
\hline 24 & 16.17 & $1.11(3 \mathrm{H}, \mathrm{s}, \mathrm{Me})$ & 16.42 & $1.32(3 \mathrm{H}, \mathrm{s}, \mathrm{Me})$ & 17.35 & $1.32(3 \mathrm{H}, \mathrm{s}, \mathrm{Me})$ & 17.35 & $1.38(3 \mathrm{H}, \mathrm{s}, \mathrm{Me})$ \\
\hline 25 & 16.27 & 0.87 (3 H, s, Me) & 17.37 & $0.91(3 \mathrm{H}, \mathrm{s}, \mathrm{Me})$ & 17.58 & $0.81(3 \mathrm{H}, \mathrm{s}, \mathrm{Me})$ & 17.58 & $0.76(3 \mathrm{H}, \mathrm{s}, \mathrm{Me})$ \\
\hline 26 & 16.41 & $0.77(3 \mathrm{H}, \mathrm{s}, \mathrm{Me})$ & 17.60 & $1.07(3 \mathrm{H}, \mathrm{s}, \mathrm{Me})$ & 16.48 & $0.96(3 \mathrm{H}, \mathrm{s}, \mathrm{Me})$ & 18.46 & $1.08(3 \mathrm{H}, \mathrm{S}, \mathrm{Me})$ \\
\hline 27 & 14.84 & $0.93(3 \mathrm{H}, \mathrm{s}, \mathrm{Me})$ & 16.14 & $1.08(3 \mathrm{H}, \mathrm{s}, \mathrm{Me})$ & 14.80 & $0.71(3 \mathrm{H}, \mathrm{s}, \mathrm{Me})$ & 14.80 & $0.82(3 \mathrm{H}, \mathrm{s}, \mathrm{Me})$ \\
\hline 28 & 177.72 & 12.03 (1 H, brs) & 177.60 & $12.03(1 \mathrm{H}, \mathrm{brs})$ & 177.98 & 12.07 (1 H, brs) & 177.75 & $12.04(1 \mathrm{H}, \mathrm{brs})$ \\
\hline 29 & 110.11 & $\begin{array}{l}4.69\left(1 \mathrm{H}, \mathrm{brs}, \mathrm{H}-29^{\mathrm{a}}\right) \\
4.56\left(1 \mathrm{H}, \mathrm{brs}, \mathrm{H}-29^{\mathrm{b}}\right)\end{array}$ & 109.96 & $\begin{array}{l}4.69\left(1 \mathrm{H}, \mathrm{brs}, \mathrm{H}-29^{\mathrm{a}}\right) \\
4.57\left(1 \mathrm{H}, \mathrm{brs}, \mathrm{H}-29^{\mathrm{b}}\right)\end{array}$ & 109.21 & $\begin{array}{l}4.69\left(1 \mathrm{H}, \text { brs, } \mathrm{H}-29^{\mathrm{a}}\right) \\
4.57\left(1 \mathrm{H}, \mathrm{brs}, \mathrm{H}-29^{\mathrm{b}}\right)\end{array}$ & 110.10 & $\begin{array}{l}4.69\left(1 \mathrm{H}, \mathrm{brs}, \mathrm{H}-29^{\mathrm{a}}\right) \\
4.57\left(1 \mathrm{H}, \mathrm{brs}, \mathrm{H}-29^{\mathrm{b}}\right)\end{array}$ \\
\hline 30 & 19.39 & 1.65 (3 H,s, Me) & 19.39 & $1.65(3 \mathrm{H}, \mathrm{s}, \mathrm{Me})$ & 19.40 & $1.65(3 \mathrm{H}, \mathrm{s}, \mathrm{Me})$ & 19.40 & 1.65 (3 H,S, Me) \\
\hline 31 & & & 172.53 & & & & & \\
\hline 32 & & & 21.55 & 1.91 (3 H,S, Me) & & & & \\
\hline
\end{tabular}

$\overline{\mathrm{a}, \mathrm{b}}$ represent the two geminal protons on $\mathrm{C}_{29}$ 


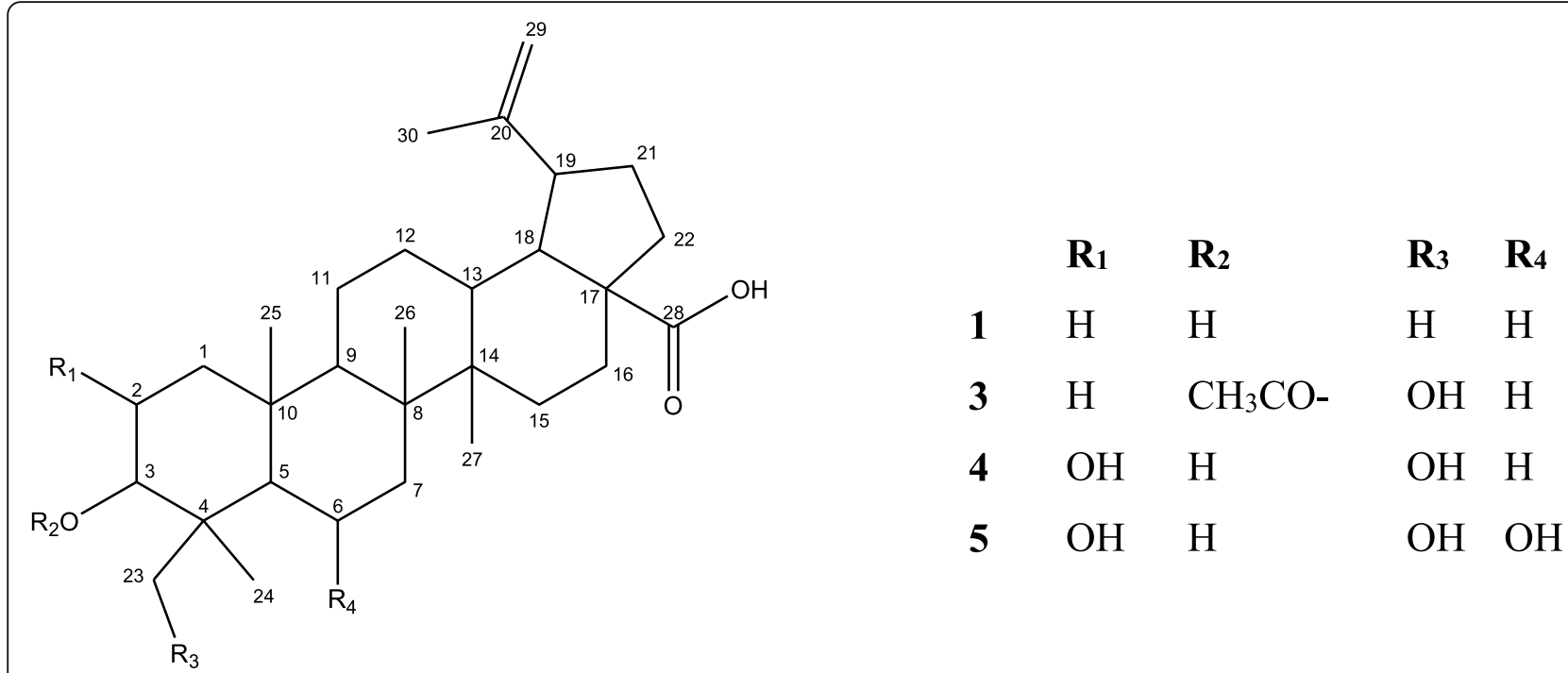

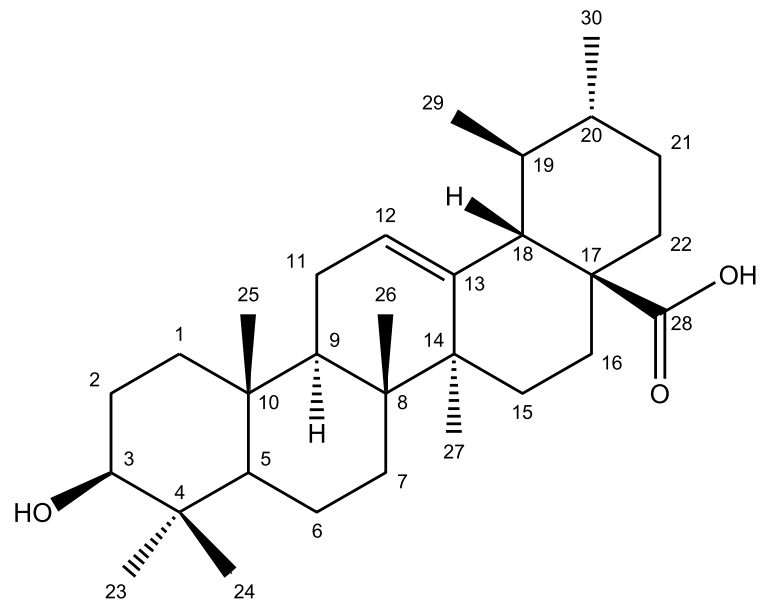

Fig. 1 Structures of the isolated compounds $1-5$ from DCMF of $C$. quadrifidus leaves

$\mathrm{H}-27, \mathrm{H}-25$ and $\mathrm{H}-26$, respectively) in addition to one proton multiplet at $\delta 3.39$ for the hydroxyl function at $\mathrm{C}-3$ and two doublets at $\delta 4.56(1 \mathrm{H}, \mathrm{d})$ and at $\delta 4.69(1 \mathrm{H}, \mathrm{d})$ respectively, characteristic for exomethylene group [11]. The structure was established through its APT ${ }^{13} \mathrm{C}-\mathrm{NMR}$ data (Table 1) which revealed the presence of carbon signal at $\delta 77.14$ confirming the hydroxylation of $\mathrm{C}-3$ as well as two olefinic carbons resonating at $\delta 150.82$ and $110.11 \mathrm{ppm}$ for the exomethylene group. Moreover the carboxylic group was established form the carbon signal at $\delta 177.72$ [12]. From the above data and in comparison to the previously available data [13, 14]; compound 1 was identified as betulinic acid.

Compound 3 was isolated as white crystals $(25 \mathrm{mg})$, $\mathrm{R}_{f}$-value $0.70(\mathrm{~S} 1)$. The spectral data of 3 were very close to 1 which gave evidence that its structure is betulinic acid derivative. ${ }^{1} \mathrm{H}$-NMR of 3 (Table 1 ) was the same as that of 1 except showing a signal at $\delta 1.91(3 \mathrm{H}, \mathrm{s})$ that is characteristic for an acetyl group which was confirmed from ${ }^{13} \mathrm{C}-\mathrm{NMR}$ (Table 1 ) by the presence of carbon signals at $\delta 21.55$ and 172.5 for methyl and ester carbonyl of acetate moiety. Also, the position of acetyl group at $\mathrm{C}-3$ was established from the downfield shift of $\mathrm{H}-3$ at $\delta 3.83$ and $\mathrm{C}-3$ at $\delta 82.52$ [15]. Moreover the presence of singlet signal integrated for $2 \mathrm{H}$, at $\delta 3.70$ with carbon signal at 63.21 together with the comparison to published data [16], gave evidence that methyl group of C-23 was replaced by hydroxyl methylene group. Based on the previous and literature data, compound 3 was identified as 3-acetyl-23-hydroxy betulinic acid.

Compound 4 was obtained as white crystals $(11 \mathrm{mg})$ with $R_{f}$-value $0.65\left(S_{1}\right)$. It was expected to have the same skeleton of 1 and 3 through comparison of their spectral data. The ${ }^{13} \mathrm{C}$-NMR spectra of 4 indicated that C-2 and 
C-23 are downfield at $\delta 67.43$ and 62.87 respectively, suggesting their substitution by a hydroxyl group [10,11]. The remaining assignments of ${ }^{1} \mathrm{H}$ and ${ }^{13} \mathrm{C}$-NMR data were in a good agreement with previously published data [17] so the structure of 4 was established as 2, 23-dihydroxy betulinic acid.

Compound 5 is white amorphous powder $(10 \mathrm{mg})$ having $\mathrm{R}_{\mathrm{f}}$-value of $0.61\left(\mathrm{~S}_{1}\right)$. Its ${ }^{13} \mathrm{C}$-NMR spectra almost resemble that of 4 with the exception of the downfield shift of C-6 at $\delta$ C 77.35 (18.46 in case of 4) which gave evidence that the C-6 is hydroxylated. Further proof of structure was achieved from HMBC spectrum which showed the most important correlations between $\mathrm{H}-3(\delta$ 3.62) with C-2 ( $\delta$ 67.66), C-23 ( $\delta 82.65)$ and H-6 ( $\delta$ 2.13) with C-7 ( $\delta 40.4), C-5(\delta 55.87)$. All remaining correlations supported that the structure of 5 is 2, 6, 23-trihydroxy betulinic acid. All data were in a good agreement with data published before [11, 18].

Compound 2 was obtained as white needles $(21 \mathrm{mg})$; $\mathrm{R}_{\mathrm{f}}$-value 0.77 (S1). IR vmax $\left(\mathrm{cm}^{-1}\right): 3422,2927,1693 .{ }^{1} \mathrm{H}$ NMR $\left(600 \mathrm{MHz}\right.$, DMSO- $\left.d_{6}\right), \delta$ ppm $0.80,0.98,1.04$, $1.08,1.10$ and $1.64(6 \mathrm{~s}, 18 \mathrm{H}$, all tertiary $-\mathrm{CH} 3), 3.39(1$ $\mathrm{H}$, brs, $\mathrm{H}-3), 5.13(1 \mathrm{H}$, brs, $\mathrm{H}-12), 2.22(1 \mathrm{H}, \mathrm{t}, J=10.82$ $\mathrm{Hz}, \mathrm{H}-15), 2.75(1 \mathrm{H}, \mathrm{d}, J=9.70 \mathrm{~Hz}, \mathrm{H}-18) ;{ }^{13} \mathrm{C} \mathrm{NMR}$ (125 MHz, DMSO): $\delta=178.72(\mathrm{C}-28, \mathrm{COOH}), 38.06$ (C-20), 19.41 (C-29), 77.29 (C-3), 47.29 (C- 17), 55.37 (C-5), 50.84 (C-9), 55.26 (C-18), 38.06 (C-19), 42.10 (C-14), 40.72 (C-8), 40.6 (C-4), 39.57 (C-1), 138.64 (C-13), 38.7 (C-10), 36.99 (C-22), 34.4 (C-7), 27.63 (C-16), 32.18 (C-21), 28.73 (C-23), 29.68 (C-2), 30.57 (C-15), 125.04 (C-12), 25.55 (C-11), 21.55 (C-30), 20.94 (C-6), 17.48 (C-26), 15.70 (C-25), 17.37 (C-24), 23.74 (C-27). Based on its spectral data as well as comparison with authentic sample and previous data, compound 2 was identified as ursolic acid [19].

\section{Antibacterial activity}

The Antibacterial activity of compounds (1-5) isolated from the DCMF of C. quadrifidus leaves was performed against four bacterial strains including two gram negative S. typhimurium and E.coli and two gram positive $S$. aureus and B subtilis (Tables 2 and 3). Compounds 4
Table 3 Minimum inhibitory concentration (MIC) as $\mu \mathrm{g} / \mathrm{mL}$ for $1-5$

\begin{tabular}{lcccccl}
\hline Bacteria & \multicolumn{2}{l}{ Compound } & & & & $\begin{array}{l}\text { Positive } \\
\text { control }\end{array}$ \\
\cline { 2 - 5 } & 1 & 2 & 3 & 4 & 5 & \\
\hline Gram + ve & 625 & 2350 & 312 & 312 & 2500 & 90 \\
S.aureus & 1250 & 5000 & 625 & 625 & 625 & 65 \\
$\begin{array}{l}\text { B.subtilis } \\
\text { Gram - ve }\end{array}$ & & & & & & Gentamycin \\
S.typhimurium & 625 & 625 & 212.5 & 125 & 125 & 100 \\
E. coli & 1250 & 1250 & 625 & 312 & 312 & 65 \\
\hline
\end{tabular}

MIC values expressed as $\mu \mathrm{g} / \mathrm{mL}$

and 5 were the most active against $S$. typhimurium $(\mathrm{MIC}=125 \mu \mathrm{g} / \mathrm{mL})$ while compound 1 and 2 showed moderate activity against the same bacteria $(\mathrm{MIC}=$ $625 \mu \mathrm{g} / \mathrm{mL}$ ). Furthermore compounds 4 and 5 exhibits a strong activity against E.coli $(\mathrm{MIC}=312 \mu \mathrm{g} / \mathrm{mL})$ and compound 3 showed moderate activity toward it (MIC = $625 \mu \mathrm{g} / \mathrm{mL}$ ). Moreover compound 3 and 4 showed strong activity against $S$. aureus $(\mathrm{MIC}=312 \mu \mathrm{g} / \mathrm{mL}$ ) and compound 1 showed moderate activity against it $(\mathrm{MIC}=$ $625 \mu \mathrm{g} / \mathrm{mL}$ ). In addition the B subtilis was moderately inhibited by compound 3, 4 and $5(\mathrm{MIC}=625 \mu \mathrm{g} / \mathrm{mL}$ ). The standard drugs used in this study were gentamycin and ampicillin for antibacterial and the antibacterial activities of compound 4 and 5 against S. typhimurium were slightly less than the activity of gentamycin.

\section{Discussion}

All isolated compounds (1-5) were previously identified from the literature but they are isolated here for the first time from the leaves of $C$. quadrifidus as well as we focused on their antibacterial activity since many studies were concentrated for search for new antibacterial agents from natural sources due to the resistance of human pathogenic microorganisms to the major antibiotics [20]. Triterpenes are known to display significant antimicrobial properties [21, 22]. Terpenoidal compounds are used in the treatment of bacterial infections due to their lipophilic properties which allow them to be easily interacting with the bacterial wall, interfering with the biosynthesis of its components as well as they can penetrate

Table 2 Antibacterial activity of the pure compounds 1-5

\begin{tabular}{|c|c|c|c|c|c|c|}
\hline \multirow[t]{2}{*}{ Bacteria } & \multicolumn{5}{|l|}{ Compound } & \multirow{2}{*}{$\begin{array}{l}\text { Positive } \\
\text { control }\end{array}$} \\
\hline & 1 & 2 & 3 & 4 & 5 & \\
\hline$\overline{\text { Gram + ve }}$ & & & & & & Ampicillin \\
\hline S.aureus & $11.03 \pm 0.45$ & $9.37 \pm 0.32$ & $13.6 \pm 0.18$ & $14.5 \pm 0.45$ & $10.03 \pm 0.95$ & $24.13 \pm 1.21$ \\
\hline B.subtilis & $10.17 \pm 0.26$ & $10.65 \pm 0.46$ & $12.5 \pm 0.44$ & $11.87 \pm 0.65$ & $11.18 \pm 0.51$ & $25.97 \pm 0.95$ \\
\hline Gram - ve & & & & & & Gentamycin \\
\hline S.typhimurium & $8.70 \pm 0.79$ & $9.78 \pm 0.65$ & $11.09 \pm 0.13$ & $15.02 \pm 0.95$ & $13.89 \pm 0.45$ & $16.97 \pm 0.95$ \\
\hline E. coli & $12.8 \pm 0.71$ & $11.9 \pm 0.35$ & $16.75 \pm 0.65$ & $17.95 \pm 0.35$ & $18.7 \pm 0.7$ & $30.03 \pm 1.05$ \\
\hline
\end{tabular}

Results were expressed as mean $\mathrm{IZ} \pm \mathrm{S} . \mathrm{D}$ 
the bacterial cell and may also interfere with protein synthesis and DNA replication and repair mechanisms. Our study showed that there were differences between the antimicrobial activities of the isolated compounds which may be due to the difference in the substation groups as well as the its position. It was shown from the biological assay results that the hydroxyl group at the position C- 23 [23] makes an important contribution to the expression of activity in compound 3,4 and 5 . Also the difference in the structure between the betulinic acid, its derivatives (compounds 1,3-5) and ursolic acid may affect the difference in activity [24].

\section{Conclusion}

The current study resulted in the identification of antibacterial triterpenoidal compounds from DCMF of $C$. quadrifidus leaves for first time. In our future study we will carry out more experimental and clinical trials to establish this finding for the development of new antibacterial natural drugs.

\section{Abbreviations}

DCM: Dichloromethane; DCMF: Dichloromethane fraction; F: Fraction; IZ: Inhibition zone; MIC: Minimum inhibitory concentration; Prep TLC: Preparative thin layer chromatography; S: Solvent system; SD: Standard deviation; SPSS: Statistical Package for Social Sciences

\section{Acknowledgments}

The authors are thankful to Dr. Trease Labib, former specialist in plant taxonomy El Orman Botanical Garden, Giza, Egypt, for identifying of the plant. We are also thankful to the Regional center of Mycology and Biotechnology (RCMB), Al-Azhar University, Cairo, Egypt, for supplying the bacterial strains used for evaluation of antibacterial activity.

\section{Funding}

The authors didn't receive financial support from any institution.

\section{Availability of data and materials}

The data sets used and/or analyzed during the current study available from the corresponding author on reasonable request.

\section{Authors' contributions}

MR revised the paper and help during the practical work, HA, DG and RR conducted the chromatographic separation of the triterpenoidal isolates, performed the structure elucidation of the pure isolated compounds and were responsible for drafting and writing the final version of the manuscript. All authors performed the antimicrobial assays and its data analysis in addition they read and approved the final manuscript.

\section{Ethics approval and consent to participate}

Not applicable.

\section{Consent for publication}

Not applicable.

\section{Competing interests}

The authors declare that they have no competing interests.

\section{Publisher's Note}

Springer Nature remains neutral with regard to jurisdictional claims in published maps and institutional affiliations.
Received: 25 December 2017 Accepted: 23 April 2019

Published online: 09 May 2019

\section{References}

1. Bailey LH. Manual of cultivated plants, Revised Edition. New York: The Macmillan Company; 1949.

2. Mabberley D J. Revolutionary botany. Thalassiophyta and other essays of A. H. Church., (Ed.) Clarendon, Oxford.1981.

3. Ayoub NA, El-Ahmady SH, Singab AN, Al-Azizi MM. Phytotherapeutic studies on Calothamnus quadrifidus R. Br (Myrtaceae). Nat Prod Ind J. 2007;3(1):30-37.

4. El Dib RA, Marzouk MS, Moharram FA, El-Shenawy SM, Elazeem RM. Chemical and biological investigation of Calothamnusquadrifidus r.Br. Bull Fac Pharm (Cairo University). 2009;47:193-202.

5. Wall PE. Thin-layer chromatography: a modern practical approach. Cambridge: The Royal Society of Chemistry; 2005.

6. Devi $A$, Singh $V$, Bhatt $A B$. In vitro antibacterial activity of pomegranate and Daru (wild pomegranate) against dental plaque bacteria. Int J Pharm Pharm Sci. 2011;3(4):182-4.

7. Clinical and Laboratory Standards Institute (CLSI). Performance standards for antimicrobial susceptibility testing, 23th informational supplement. Pennsylvania: CLSI: M100-S23; 2013.

8. Vogel NW, Taschetto AP, Dall'Agnol R, Weidlich L, Ethur EM. Assessment of the antimicrobial effect of three plants used for therapy of communityacquired urinary tract infection in Rio Grande doSul (Brazil). J Ethnopharmacol. 2011:137(3):1334-6.

9. Sholichin $\mathrm{M}$, Yamasaki $\mathrm{K}$, Kasai $\mathrm{R}$, Tanaka $\mathrm{O} .{ }^{13} \mathrm{C}$ nuclear magnetic resonance of Lupane-type triterpenes, Lupeol, Betulin and Betulinic acid. Chem Pharm Bull. 1980;28(3):1006-8

10. Ahmad VU, Rahman AU. Handbook of Natural Products Data. Volume 2. Amsterdam: Pentacyclic Triterpenoids; Elsevier; 1994. p. 1-1200.

11. Bisoli E, Garcez WS, Hamerski L, Tieppo C, Garcez FR. Bioactive pentacyclic triterpenes from the stems of Combretum laxum. Molecules. 2008;13(11):2717-28.

12. Mahato SB, Kundu AP. 13C NMR spectra of pentacyclic triterpenoids-a compilation and some salient features. Phytochemistry. 1994;37(6):1517-75.

13. Haque ME, Shekhar HU, Mohamad AU, Rahman H, Islam AM, Hossain MS. Triterpenoids from the stem bark of Avicennia officinalis. Dhaka Univ J Pharm Sci. 2006:5(1):53-7.

14. Prakash CV, Prakash I. Isolation and structural characterization of Lupane triterpenes from Polypodium vulgare. Res J of Pharmaceutical Sci. 2012;1(1):23-7.

15. Ahmad FB, Ghaffari Moghaddam M, Basri M, Abdul Rahman MB. Anticancer activity of 3-O-acylated betulinic acid derivatives obtained by enzymatic synthesis. Biosci Biotechnol Biochem. 2010;74(5):1025-9.

16. Ghaffari M, Basri M, Rahman MA. Spectroscopic data of 3-O-acetyl-betulinic acid: an antitumor reagent. Asian J Chem. 2010;22(4):3186.

17. Bi Y, Xu J, Sun F, Wu X, Ye W, Sun Y, Huang W. Synthesis and biological activity of 23-hydroxybetulinic acid C-28 ester derivatives as antitumor agent candidates. Molecules. 2012;17(8):8832-41.

18. Estrada O, Contreras W, Acha G, Lucena E, Venturini W, Cardozo A, Alvarado-Castillo C. Chemical constituents from Licaniacruegeriana and their cardiovascular and antiplatelet effects. Molecules. 2014;19(12):21215-25.

19. Seebacher W, Simic N, Weis R, Saf R, Kunert O. Spectral assignment and reference data: complete assignments of $1 \mathrm{H}$-and $13 \mathrm{C}$ NMR resonances of oleanolic acid, 18-a-oleanolic acid, ursolic acid and their 11-oxoderivatives Magn Resonances Chem. 2003;41:636-8.

20. Karaman I, Şahin F, Güllüce $M$, Öğütçü $H$, Şengül $M$, Adıgüzel $A$. Antimicrobial activity of aqueous and methanol extracts of Juniperus oxycedrus L. J Ethnopharmacol. 2003;85:231-5.

21. Tene M, Ndontsa LB, Tane P, Tamokou JD, Kuiate JR. Antimicrobial diterpenoids and triterpenoids from the stem bark of Croton macrostachys. Int J Biol Chem Sci. 2009:3:538-44.

22. Chouna JR, Tamokou JD, Nkeng-Efouet-Alango P, Lenta NB, Sewald N. Antimicrobial triterpenes from the stem bark of Crossopteryx febrifuga. Zeitschrift für Naturforschung C. 2015:70(7-8):169-73.

23. Djoukeng JD, Abou-Mansour E, Tabacchi R, Tapondjou AL, Bouda H, Lontsi D. Antibacterial triterpenes from Syzygium guineense (Myrtaceae). J Ethnopharmacol. 2005;101(1-3):283-6.

24. Fontanay S, Grare M, Mayer J, Finance C, Duval RE. Ursolic, oleanolic and betulinic acids: antibacterial spectra and selectivity indexes. J Ethnopharmacol. 2008:120(2):272-6. 